AIBR

Revista de Antropología Iberoamericana

www.aibr.org

VOLUMEN 6

NÚMERO 2

MAYO-AGOSTO 2011

Pp. 135-157

Madrid: Antropólogos Iberoamericanos en Red. ISSN: 1578-9705

\section{CO-ONTOGENIA: HUMANO E NÃO-HUMANO NO ESPAÇO DA LINGUAGEM.}

BETO VIANNA I UNIVERSIDAD FEDERAL DE MINAS GERAIS (BRASIL)

A versão original em português deste artigo está disponível gratuitamente na edição eletrônica da revista. 


\section{RESUMEN:}

A linguagem tem sido estudada, desde meados do século passado, em seus aspectos biológicos e cognitivos, sempre no contexto de uma biologia e de uma cognição especificamente humanas. Ainda assim, há aspectos do viver e do conhecer que remetem ao seres vivos em geral, e não apenas aos humanos, e que são cruciais para se falar nos processos gerativos da linguagem, ou seja, os relacionamentos recorrentes e recursivos entre dois ou mais organismos (co-ontogenia) que estabelecem vivências partilhadas entre esses organismos. Para falar sobre esses aspectos é preciso superar o discurso estritamente objetivista da ciência e atentar para o papel que nós, investigadores e leitores de trabalhos acadêmicos, exercemos ao descrever comportamentos lingüísticos. Utilizando o caminho explicativo de determinadas teorias sistêmicas e relatos de meu contato com grandes símios não-humanos na Alemanha, argumento que o viver e o conhecer de organismos humanos e não-humanos, e o nosso viver e conhecer enquanto observadores desses organismos, são igualmente instrumentais na explicação das relações co-ontogênicas recorrentes e do fenômeno a que chamamos linguagem.

\section{PALABRAS CLAVE:}

linguagem, cognição, co-ontogenia, grandes símios, biologia do conhecer

\section{SUMMARY:}

Language has been well studied, since the middle of last century, in its biological and cognitive aspects, always in the context of a specifically human biology and cognition. Still, there are aspects of living and knowing that refer to living beings in general and not restricted to humans, which are crucial to address processes that generate language, that is, the recurrent and recursive relationships between two or more organisms (co-ontogeny) which establish shared experiences among them. For talking about these issues it is necessary to overcome the strictly objectivist discourse of science and pay attention to the role we, researchers and readers of academic material, play in describing linguistic behavior. Using the explanatory path of specific systems theories and reports of my contact with nonhuman great apes in Germany, I argue that the living and knowing of human and nonhuman organisms and our living and knowing as observers of these organisms are equally instrumental in explaining the recurring co-ontogenic relations and the phenomenon we call language.

\section{KEY WORDS:}

language, cognition, coontogeny, great apes, biology of knowledge

RECEPCIÓN: 27.10.2010

ACEPTACIÓN: 15.04.2011

\section{AGRADECIMENTOS:}

Agradeço imensamente a Rubén Gómez-Soriano, David Martín Castro, Sergio López e Renata Barbosa por sua contribuição para este artigo. Nem preciso dizer que os erros seguem sendo de minha exclusiva autoria. 


\section{Introdução}

No zoológico de Leipzig, vivia, por volta de 2004, uma imponente tigresa adulta. Nessa época, por conta de uma bolsa de doutorado-sanduíche, passei uma temporada como aluno visitante no Instituto Max Planck de Antropologia Evolutiva, onde tive a oportunidade de trabalhar como ajudante de pesquisa no Departamento de Psicologia, sob a orientação de Michael Tomasello. Os sujeitos experimentais eram nossos irmãos taxonômicos, os grandes símios não-humanos - chimpanzés, bonobos, gorilas e orangotangos - cativos naquele zoológico. Ao cair da tarde, saindo do laboratório, passávamos todos pelos fundos dos recintos noturnos do zoo, e no meio do caminho havia a tigresa. Livre do horário de visitação, a gata rondava a cela naquele autismo característico do felino enjaulado, de um canto a outro, repetidamente. Imagine um entardecer do inverno alemão, o céu rubro-cinza cortado pela silhueta da tigresa em movimento, só os olhos brilhando. Muitos de nós não víamos ali um pobre animal aprisionado, mas uma fera poderosa, pronta para saltar sobre o cardápio de alunos, pesquisadores e doutores com suas respectivas reputações acadêmicas.

Se perguntarmos a um biólogo ou psicólogo de inclinações neodarwinistas (a leitura hegemônica de Darwin nos últimos 70 anos) o motivo de tanto respeito por um animal enjaulado, privado de ações espetaculares, ele ou ela dirá que se trata de um "medo ancestral". $\mathrm{Na}$ aurora da humanidade, segue o argumento, não éramos nem sombra dos dominadores da natureza que somos hoje, mas subsistíamos precariamente, evitando os predadores como qualquer outra presa. Como nossos antepassados sobreviveram sob aquelas condições, e, é claro, deixaram descendentes, aqui estamos nós hoje, assombrados por grandes felinos, serpentes e aves de rapina, inclusive na cidade grande, onde o assombro não tem o respaldo da experiência cotidiana. Mesmo sem compreender os detalhes do mecanismo darwiniano subjacente a esse temor arquetípico, percebemos que esse relato não é trivial, mas está repleto de significados sobre a origem dos significados. Ou, para ser mais explícito, sobre o modo como nós, mergulhados no universo das explicações científicas, chegamos a falar dessa maneira sobre a origem dos significados.

Em lingüística, "significado" não é um conceito incontroverso, mas, em geral, aceita-se que ele remete a um aspecto do signo lingüístico pertinente, portanto, apenas ao universo do humano - que nos permite "selecionar um ou outro aspecto do mundo não-lingüístico" (Trask, 2006: 265). Para que o significado cumpra o que promete, ele deve, ao 
mesmo tempo, "denotar" (apontar para algo no mundo) e ter "sentido" (relacionar-se com os demais signos de um sistema lingüístico). Assim, a expressão "a tigresa do zoo de Leipzig” denota um ser no mundo e pode significar algo a se temer, na medida em que se relacione, por exemplo, a "grande felino", ou "animal ameaçador no passado do humano".

Ainda que a lingüística seja uma ciência relativamente nova, a preocupação com o significado é de estirpe mais antiga. Há mais de dois mil anos, Platão apresentava, no Crátilo (1994), uma discussão que ainda sobrevive, sobre as palavras serem artifícios humanos ou relacionarem-se naturalmente às coisas. O sucesso do texto seminal de Saussure (1992), no início do século XX, foi tomar como hipótese de trabalho a "arbitrariedade do signo" e concentrar a discussão da língua enquanto sistema: a investigação de suas relações internas como condição para uma ciência lingüística. Por outro lado, o filósofo Charles Sanders Peirce nos legou um sistema explicativo bem mais sofisticado para os intrincados processos de significação - a semiótica (Teixeira Coelho Netto, 1999) - nunca totalmente assimilado pelas ciências lingüísticas, mais à vontade com as dicotomias saussureanas. Peirce introduzia exatamente o que o lingüista dinamarquês Louis Hjelmslev chamava de "contaminações transcedentais" (Teixeira Coelho Netto, 1999:55), ou seja, os efeitos práticos, presentes e futuros das proposições lingüísticas, e não apenas as dinâmicas internas ao discurso.

Correndo o risco de aproximar conceitos muito rapidamente, digo que, trazer à mão o significado de alguma coisa (de uma palavra, de um comportamento, de uma circunstância) é conhecer essa palavra, esse comportamento ou essa circunstância. Séculos de filosofia ocidental nos ensinaram que conhecer é conhecer algo, o que tanto pode ser determinado por esse algo ou imposto a ele por nós mesmos, sujeitos cognescentes. Assim, segundo a corrente filosófica em questão, é nas coisas do mundo ou, alternativamente, em nossa res cogitans - a alma, a mente ou o cérebro, dependendo de nossas preferências epistemológicas - que devemos encontrar a matéria-prima do conhecimento (Vianna, 2004). Uma terceira via, popularizada na síntese de Kant (1980), é a interação entre a matéria-prima do mundo e o artesão cognitivo: apreendemos realidades mal estruturadas e colocamos sentido em um mundo originalmente confuso.

Nas alternativas acima, a relação estabelecida entre um mundo lá fora e nosso equipamento para compreender esse mundo é uma relação entre instâncias causais distintas, e colocar a ênfase em uma delas, ou assumir um "caminho-do-meio" interacionista não nos livra de um quadro conceitual que se mostra bastante limitado quando decidimos fazer per- 
guntas mais complicadas. Por exemplo, como acontece que cada um de nós enquanto ser vivo, enquanto um organismo individual operando em um mundo, possa partilhar conhecimento com outros organismos? Essa questão costuma suscitar descrições referenciais (semânticas), ou, como é moeda corrente nas ciências cognitivas, de representações mentais. Mas não vejo, nesse caminho, como estender a pergunta sobre o conhecimento compartilhado, o significado público de que fala uma tradição da filosofia da linguagem desde Wittgenstein, Austin, Sellars e outros (Rorty, 1995), para o operar do vivo. Ao contrário, penso que faríamos melhor em abdicar dessa linguagem de referências a um mundo prévio e de representações, se queremos falar de maneira produtiva sobre as relações que nós, organismos, estabelecemos uns com os outros e nos permite trazer à mão os mais diversos e, às vezes surpreendentes, objetos comuns.

Pretendo costurar, portanto, um encontro entre teorias situadas e não-referenciais do significado e explicações situadas e não-representacionais do organismo, esperando que isso torne menos atrativo o discurso acadêmico que defende a causação linear como explicação de fenômenos complexos, como é o caso dos processos cognitivos humanos e não-humanos. Isso envolve, também, entender as descrições que fazemos de como essa cognição vem a ser o que é historicamente, tanto na história evolutiva dos organismos, quanto em sua ontogênese (o desenvolvimento do nascimento à morte individual) e em sua "micro-gênese", ou seja, as atividades do organismo aqui e agora. Como não sou biólogo ou psicólogo, mas lingüista por formação, ao falar de cognição e evolução devo falar também da linguagem, um fenômeno implicado pelos dois outros (e nos dois outros), o que é geralmente aceito na literatura acadêmica, ao menos no que se refere ao humano, mas nem sempre a partir do domínio explicativo que vou assumir neste artigo.

Como subsídio teórico, vou utilizar sistemas explicativos que me parecem particularmente úteis para falar de cognição e evolução, como a Biologia do Conhecer (Maturana e Varela, 1973), a Teoria dos Sistemas em Desenvolvimento (Oyama, 2000) e a Teoria da Deriva Natural (Maturana e Mpodozis, 1992). Como caso a observar, apresento relatos de meu convívio com símios não-humanos durante minha estada no Centro de Pesquisas Primatológicas Wolfgang Köhler, do Instituto Max Planck de Antropologia Evolutiva, Leipzig, em 2003 e 2004. 


\section{Cognição: Padana e o observador}

Os experimentos de que participei em Leipzig fazem parte da indagação, no contexto da psicologia comparada, sobre as habilidades contábeis dos grandes símios não-humanos. Eram apresentados dois recipientes com quantidades distintas de ração aos sujeitos, que "acertavam" ao tocar com o dedo (às vezes a língua) o recipiente com a maior quantidade. Em qualquer circunstância, o prêmio era o conteúdo do recipiente escolhido. Presumindo que os símios de fato preferem a quantidade maior, e apesar da advertência de que a pesquisa não objetivava "avaliar a competência numérica (...) dos sujeitos” (Hanus e Call, 2007, p. 248), não há dúvidas de que perguntar pela habilidade de discriminar quantidades em uma classe de organismos, é perguntar por uma característica comum a toda essa classe. No caso, trata-se explicitamente uma capacidade cognitiva que pode ou não "ser possuída” pelos grandes símios não-humanos, e passível de investigação experimental.

Uma variável do experimento é a "grandeza" das quantidades: os recipientes podiam conter 2 e 3 unidades, ou, digamos, 7 e 10. E de fato, para a maioria de nós, a conta costuma ficar mais difícil quando envolve mais unidades ${ }^{1}$. Além da grandeza, a diferença e a razão entre os montantes também interferem na comparação entre quantidades. Os pares 2-4 e 8-10 possuem diferenças semelhantes (2) e razões distintas $(0,5$ e 0,8$)$, ao passo que 2-4 e 4-8 possuem a mesma razão $(0,5)$ e "diferenças diferentes" (na pesquisa, constatou-se que o aumento da razão era o grande fator de diminuição dos "acertos"). No Experimento $1^{2}$, havia duas condições de apresentação: os recipientes eram apresentados abertos, simultaneamente, ou seja, o sujeito podia checar o conteúdo dos recipientes na hora de escolher; ou os recipientes eram abertos sequencialmente e apresentados fechados para a escolha, ou seja, era preciso lembrar o que se viu para decidir.

Podemos imaginar que é mais fácil discriminar objetos bem à nossa frente do que operar sobre algo distante da percepção imediata. Pensamos, além disso, que a "ausência de linguagem" deve impor um limite adicional à capacidade de representar realidades não percebidas aqui e agora. Mas os resultados da pesquisa não mostram nenhuma diferença significativa entre as condições simultânea e seqüencial, o que, segundo os autores, confirma "dados anteriores mostrando que símios são capazes de discriminar

1. Podemos estimar quantidades pequenas sem contar item por item, mas por um processo de "percepção global", ou subitizing, em inglês (Hanus e Call, 2007). Além de um certo montante, porém, esse sistema deixa de funcionar, tanto para humanos quanto para outros organismos.

2. No Experimento 1, as unidades eram apresentadas em conjunto, em recipientes rasos, e no Experimento 2, a unidades eram "pingadas" uma a uma, à vista do sujeito, em um copo opaco. 
entre quantidades mesmo impedidos de ver ambas as quantidades simultaneamente" (ver Hanus e Call, 2007: 244; tradução e ênfase minhas). Ou seja, cognição parece ter a ver com a uma capacidade que se possui ou não, e em um nível maior ou menor de complexidade dependendo da classe de organismos a que se pertence, mesmo que isso dependa de uma interação do organismo com os dados do mundo (ver ou não ver as quantidades simultaneamente; distinguir entre quantidades maiores e menores). Mas é desse jeito que funcionamos como organismos?

Padana, uma fêmea orangotango (Pongo pygmaeus) de 7 anos na época dos testes, sentia um prazer particular em brincar com o experimentador, o que permitia, entre um jogo e outro, realizar os testes sem muita necessidade de negociação extra. É claro que esse "brincar” às vezes interferia na realização dos testes e, por outro lado, nem sempre era claro pra mim se Padana configurava o próprio teste como um momento prazeroso. Em uma ocasião, pelo menos, me dei conta que a diferença que eu fazia entre "teste" e "brincadeiras" não era fundamental para a dinâmica de minhas relações com Padana, e, sim, aceitar ou não as ações da jovem orangotango em ambas as situações que, para mim, eram distintas: as brincadeiras $e$ os testes.

Eu realizava com Padana o Experimento 1 e um dos testes apresentava quantidades relativamente pequenas nos recipientes, 2-3 (razão de 0,7). Os recipientes foram abertos em condição simultânea: as unidades de ração estavam lá, à vista de quem quisesse ver. Mas Padana, que costumava acertar em uma taxa acima do mero acaso, apontou a quantidade menor. No linguajar que aprendi em minhas interações humanas (talvez com um pouco de "simiês", a exemplo do que lamentavelmente fazemos com cachorros e crianças) externei para Padana o meu descontentamento com a sua performance, e a reação veio em seguida, ou melhor, no teste seguinte. Um par de recipientes com quantidades 2-1 foi aberto sequencialmente para a observação de Padana. Ostensivamente (ou seja, de modo notável para mim), ela desviou o olhar ao ser aberto cada recipiente, e no momento da escolha, tocou com o dedo a quantidade correta, ou seja, a quantidade esperada. Após cumprimentos recíprocos, engajamo-nos em um demorado jogo de cobrança de pênalti: Padana se colocava no fundo do recinto, de costas contra a parede, e eu atirava uma uva, que ela tinha de agarrar (infelizmente um orangotango jovem é ágil demais, com seus braços fortes e imensos, e eu raramente conseguia fazer um gol) ${ }^{3}$.

A essa altura, uma queixa usual dos cientistas é a de antropomorfis-

3. Com a exceção do jogo de cobrança de pênalti, o episódio está disponível em vídeo na internet, no endereço http://www.biolinguagem.com/bioimagens/videos_zooleipzig/padana_10_03_04.wmv 
mo: atribuir, a outros organismos, comportamentos pertinentes apenas ao humano. Mas se quero me referir àquilo que permite que Padana realize determinadas ações num dado momento - a sua emoção - a questão do antropomorfismo é absolutamente secundária. É ao observar Padana assumir tais e tais disposições corporais que posso dizer que ela, por exemplo, poderá participar do experimento, ou, então, ela quer brincar. É claro que, na publicação acadêmica da pesquisa que estou relatando, nenhuma referência é feita a essas mudanças de disposição, a não ser em um aspecto: a ação de discriminar entre quantidades. Mas isso é tomado como um atributo cognitivo, um representar o mundo de uma dada maneira (o que, implicitamente aponta para uma maneira correta e outra equivocada de efetivar essa representação). Minha discussão aqui, no entanto, trata de algo bem diferente: não da representação, mas da configuração do mundo como um ato de conhecer. Nesse caso, o que é relevante é se aquilo que Padana faz, no momento em que faz, permite que ela realize o seu viver, ainda que esse comportamento seja necessariamente descrito por mim, pelo observador, e aceito como tal pela comunidade de observadores a que me dirijo. No próprio operar do organismo - no ato de conhecer - não há espaço para a distinção entre equívoco e erro, ainda que nós, observadores, possamos distinguir entre equívoco e erro ao descrever esse operar.

Admito que não é desse modo que costumamos empregar o termo "cognição". Mas isso tem a ver com as advertências que fiz na Introdução, sobre conservarmos determinadas noções, como a referência a um mundo prévio e operações sobre representações mentais. A utilização dessas noções é, muitas vezes, defendida contra um relativismo pernicioso, que impediria um acesso aos dados da natureza "tal como eles são", e como se a atividade científica dependesse da objetividade para realizar suas tarefas de descrever e explicar. O antropólogo Clifford Geertz (2001) já nos alertou como é infundado um medo do relativismo, principalmente em áreas como o estudo das culturas humanas etnografia, que demandam uma atenção ao que se diz no "outro lugar". A cognição e a linguagem têm também essa propriedade situada, dependente de nossa interpretação daquilo que se conhece ou diz em “outro lugar”. E desde Thomas Kuhn (2001), e, principalmente desde Latour (1993), sabemos que esse “outro lugar” é, inclusive, o nosso: nossa comunidade científica, nossa comunidade ocidental, e, se formos inclusivos o suficiente nas descrições, toda a nossa comunidade $h u$ mana de observadores. Não fazemos nada fora das coerências descritivas do nosso próprio grupo.

A escola chilena da Biologia do Conhecer, cujos fundamentos epistemológicos foram lançados nos anos 70 por Humberto Maturana e 
Francisco Varela (1973), propõe explicar a cognição (mostrando o que acontece com o ser vivo enquanto um sistema fechado e dinâmico (que produz e é produzido por seus componentes e pelas relações entre eles) e, por outro lado, como uma totalidade em sua relação com o meio. E faz isso deixando explícito o papel do observador, ou seja, aquele que é responsável pela distinção tanto do domínio do organismo como uma rede dinâmica de componentes quanto do organismo operando em um meio. O observador, no nosso caso, é um cientista, o cientista é um humano e o humano é um ser vivo. Isso implica que tudo o que a teoria disser sobre o vivo, em geral, aplica-se também, e necessariamente, ao observador.

$\mathrm{Na}$ Biologia do Conhecer, explicar é propor, a partir da própria experiência, a reformulação de um fenômeno de modo aceitável para uma comunidade de observadores que partilha os mesmos critérios de validação daquele que está explicando. O que é próprio à explicação científica (e diferente das muitas outras coerências explicativas existentes na nossa e em outras culturas) é a utilização de um critério específico para validar a explicação, preenchendo as seguintes condições: a) apontar um fenômeno aceitável na experiência da comunidade de cientistas; b) propor um sistema conceptual que gere tal fenômeno (também aceitável para essa comunidade); c) apontar outros fenômenos que possam ser gerados no sistema proposto; d) e, finalmente, gerar esses novos fenômenos no sistema explicativo proposto, validando, assim, a explicação (Maturana e Varela, 1998:28). Cada etapa do critério de validação das explicações científicas deve ser cumprida em termos da experiência do observador, e, não, fazendo referência a uma realidade independente. Não faz parte do explicar apontar para um mundo que preexiste a explicação ainda que, vez ou outra, alguém o faça como uma "petição de obediência": minha teoria é a correta pois está de acordo com os dados da natureza (e de fato está, ainda que provisoriamente, pois o mecanismo explicativo foi criado justamente para gerar esses fatos!).

Outra exigência na Biologia do Conhecer é que, em uma explicação mecanicista, é preciso distingüir entre um sistema e seus componentes, tratando-os como "unidades operacionalmente diferentes, que pertencem a conjuntos discretos que geram domínios fenomênicos que não se intersectam" (Maturana, 1997:127). Isso é o exatamente o que um observador faz quando distingüe os componentes de um sistema vivo (a fisiologia), e, de outro lado, o operar desse sistema em um meio (o comportamento): dois domínios diferentes, operacionalmente disjuntos. $\mathrm{O}$ observador pode descrever correspondências entre a a fisiologia e o comportamento, mas através de sua interação com os dois domínios, e, não, como uma redução 
fenomêmica. Finalmente, um objeto de inquirição não pode aceitar instruções a partir de um agente externo: tudo o que acontece ao sistema deve ser determinado, a qualquer momento, por sua própria estrutura. Quando o sistema é dinâmico (como é o caso do ser vivo), cada mudança estrutural irá acarretar novas possibilidades no que diz respeito ao que pode e o que não pode acontecer com esse sistema.

Assim, o meio não instrui o organismo, ainda que, seguindo uma história de interações organismo-meio, ambos mudem suas estruturas de modo correspondente. Não há espaço, no caminho explicativo que estou seguindo aqui, para a noção de representação, ou seja, a noção de que aquilo que ocorre com o organismo (a sua fisiologia) é sobre as informações do ambiente. $\mathrm{O}$ ato de conhecer está no domínio das coerências observadas do organismo operando em um meio, e não na fisiologia. Em sua história de interações com o meio, e em contínua mudança estrutural, o organismo realiza e conserva sua organização de ser vivo ${ }^{4}$.

Ao deslizar entre quantidades e apontar para uma delas, Padana realiza uma seqüência de ações que satisfaz os critérios colocados por uma comunidade de cientistas, que, assim, poderá dizer que o comportamento observado da jovem orangotango é de tal tipo, tem tais características etc. E, como observadores, podem dizer se tal comportamento é "certo" ou "errado" (dentro das coerências descritivas de sua comunidade de observadores). Mas do ponto de vista das efetivas operações do organismo, a conservação da correspondência com o meio em contínua mudança estrutural é necessária e suficiente: é a condição para Padana estar viva, e, portanto, sua condição de conhecer. O mesmo acontece conosco. Viver e conhecer, biologia e cognição, são sinônimos operacionais para orangotangos, humanos ou qualquer outro sistema vivo, ainda que possamos descrever de maneira bem diferente o que ocorre em cada classe de organismos dentro das coerências descritivas de nossa comunidade conversacional.

\footnotetext{
4. Na Biologia do Conhecer, a distinção entre estrutura e organização é crucial para falar sobre conservação e mudança em um sistema vivo. Os componentes de um sistema e as relações entre eles especificam a classe de sistemas sobre a qual estamos falando: é sua organização, que é, portanto, invariante. Mas os componentes e relações particulares - a estrutura - podem variar sem perda da identidade do sistema. É isso o que acontece com cada organismo, do seu surgimento como unidade autônoma até a sua morte: vive em contínua mudança estrutural sem perda de identidade, ou seja, com conservação da organização (Maturana e Varela, 1997).
} 


\section{Evolução: a deriva natural de N’Kwango}

Em Leipzig, as fêmeas adultas Bebe e N'diki tinham, em comum, o fato de serem jovens mães gorilas e terem nascido "na natureza", como se diz no jargão zoológico. Mas viviam circunstâncias bastante distintas. Um problema de gorilas em cativeiro (além do próprio cativeiro) é o “excesso" de machos. Nos zoológicos, é comum, por falta de espaço adequado, grupos de um só macho, e não grupos múltiplos e intercambiáveis, que é o modo de vida gorila usual nas dinâmicas das populações selvagens (Bradley, Doran-Sheehy, Lukas e Boesch, 2004). Machos jovens ao atingir certa idade, são transferidos para outra instituição. Bebe vivia tranqüila com sua filha Ruby, de 6 anos, mas N'diki tinha um filho macho - N’kwango - mesma idade de Ruby. À época de minha estada em Leipzig, ele era mantido separado do restante do grupo, aguardando a transferência, uma situação perturbadora para $N^{\prime}$ diki, que, contrastando com a placidez de Bebe, mostrava-se constantemente irritada nos experimentos (Vianna, 2006:332-333). O filho N’kwango, apesar de tudo, assumia uma atitude exemplar como sujeito de experimentação.

No Experimento 2 (ver nota 2 deste artigo), em que as unidades de ração são "pingadas" no recipiente, $\mathrm{N}^{\prime}$ Kwango aguardava, atento, todo o procedimento. Quase sempre o gorila apontava a quantidade "certa", mas o que mais impressionava era a paciência com que N’Kwango observava até 19 unidades de ração serem depositadas, uma a uma, à sua frente. A própria ração não parecia especialmente motivadora, pois todos símio preferia as frutas frescas oferecidas antes e depois do experimento (ainda que a distribuição de "prêmios" em alimento, seja qual for, acabe virando um habitus na vida de quase todo animal cativo submetido a experimentos psicológicos). Uma explicação do comportamento de N’kwango é a sua condição de gorila. Não apenas por que a espécie possui modos típicos de se comportar, que, antropomorficamente, podemos chamar de tranquilos, ou pacientes (apesar do que vimos em relação a N’diki), mas, por se tratar de um grande símio africano, uma linhagem de organismos genealogicamente muito próxima do humano, esperarmos uma complexidade e flexibilidade comportamentais ausente em outros organismos. Essas são explicações evolutivas para a cognição e a conduta, mas que podem ser abordadas de modo muito diferente dependendo do caminho explicativo que escolhemos seguir.

O gorila foi, talvez, o primeiro grande símio a surgir para o observador ocidental, ora abalando nossas certezas descontinuístas, ora como um precioso elo entre o humano e o restante do mundo vivo na "Grande 
Cadeia do Ser" (Lovejoy, 1998). O termo latino gorilla tem origem antiga, utilizado pelo cartaginês Hanno em suas viagens pela costa da África Ocidental por volta de 500 a.C., ao descrever um "povo peludo" que tanto poderiam ser gorilas (na denotação atual), algum tipo de macaco, ou seres humanos (Groves, 2002). Um texto de 1625 que narra as observações de um certo Andrew Battell (prisioneiro dos portugueses em Angola) sobre o "Pongo" uma fera misteriosa: "semelhante a um homem em todas as suas proporções mas com a estatura de um gigante” (Huxley, 2001: 3-4). Finalmente, o missionário Thomas Savage obtém, na Libéria, o primeiro "espécime" (um crânio e alguns ossos) para o ocidente científico e, em 1847, publica a descrição do que denominou Troglodytes gorilla ${ }^{5}$. Desde Hanno, “a história do gorila está intimamente relacionada à brutal história de colonização da África” (Gómez-Soriano e Vianna, 2008:188; tradução minha) e ao debate sobre a continuidade ou descontinuidade biológica do humano, antes e depois de Darwin. Essa questão também possui os dois pés firmemente plantados na África, epistemológica e politicamente, na medida em que o "racismo científico" se serviu tanto da concepção dos tipos humanos como criações divinas, imutáveis, quanto de uma interpretação perigosamente distorcida da evolução darwiniana.

O gorila foi a principal munição de Thomas Henry Huxley, darwinista histórico e amigo de Darwin, no combate à idéia da criação imutável das espécies. Man's place in nature, de 1863 (Huxley, 2001), é, nas palavras de Steve Gould, "sua publicação mais admirável e influente, que se tornou um marco na história da prosa científica” (Gould, 2003:153). Mas foi o adversário de Huxley, o anatomista Richard Owen, hoje considerado um tipo de vilão científico por se opor à evolução, quem, em um artigo de 1863, mostrou que o evolucionismo huxleyano pecava justamente por seu tratamento ingênuo, para dizer o mínimo, das continuidades evolutivas observadas (Gould, 2003; Gómez-Soriano e Vianna, 2008). No meio científico atual, é consensual o fenômeno da evolução orgânica, e igualmente consensual a noção de que o humano não apenas é um grande símio, mas um grande símio africano: humanos, chimpanzés, bonobos e gorilas estão todos "no mesmo galho" evolutivo, e igualmente distantes do grande símio asiático, o orangotango.

No século XIX, Darwin e Huxley tiveram o mérito de nos mostrar isso com uma argumentação primorosa baseada em pouquíssimas evidências (Darwin, 1974). Desde a década de 1960 (Lewin, 1999), todas as fon- 
tes - moleculares, anatômicas, paleontológicas, geográficas - passaram a conspiram elegantemente para, enfim, fazer justiça à hipótese africana de Darwin-Huxley. O problema é que Huxley, em seu ardor evolucionista, buscou encurtar o fosso entre o humano e o gorila estabelecendo escalas dentro da espécie humana, e, como você deve ter adivinhado, os negros estariam mais próximos, que o branco, da ponta "inferior". Foi preciso que o criacionista Owen mostrasse o que hoje é evidente para a maioria de nós: diferenças intra-específicas não são bons guias para variações interespecíficas (Gould, 2003). Traduzindo para a genealogia, não há “escalas internas de parentesco": entre dois irmãos, cada um é tão aparentado com um primo quanto o outro. Em dimensões evolutivas, isso significa que todo humano (aliás, todo humano, chimpanzé e bonobo) possui o mesmo grau de parentesco com o gorila gorila. É claro que Owen não via um significado evolutivo nessa lógica da afinidade, e, portanto, concordamos com Huxley em todo o resto. Mas 150 anos após esse debate, continuamos à volta com noções mal formuladas acerca da evolução orgânica, duas delas bastante semelhantes ao pecado de Huxley: o progressivismo - a idéia de que o percurso evolutivo é a produção de organismos intrinsecamente melhores - e o adaptacionismo - em que um processo de adaptação diferencial produz, exatamente, tais organismos superiores.

Em A origem das espécies, Darwin já fizera notar que, ao falar de "seleção" e "luta pela existência", utilizava metáforas potencialmente enganosas. No primeiro caso, certas variedades naturais deixavam descendentes como se houvessem sido selecionadas. Por isso Darwin dedica todo o capítulo I à "Variação em estado doméstico" (Darwin, 2002:41-68), onde a seleção, propriamente dito, é utilizada como argumento para uma teoria da descendência com modificação na natureza. Quanto à luta pela existência, vale escutar o próprio Darwin (2002:79):

Devo estabelecer como premissa que emprego a expressão "luta pela existência” em sentido amplo e metafórico, incluindo nesse conceito a idéia de interdependência dos seres vivos, e também - o que é mais importante - não só a vida de um indivíduo, mas sua capacidade de deixar descendência. Dois canídeos, num período de escassez de alimentos, literalmente hão de lutar entre si a fim de assegurar sua sobrevivência; todavia, ao invés de dizermos que uma planta que vive nas bordas do deserto enfrenta a seca lutando pela sobrevivência, melhor seria se disséssemos que ela depende da umidade para sobreviver. 
Resumindo a teoria darwiniana da seleção natural, podemos dizer que: 1) os organismos variam (comportamental e fisiologicamente); 2) as variações são de algum modo herdadas; 3) variantes diferentes reproduzem-se em taxas e quantidades diferentes, o "sucesso reprodutivo diferencial". As variantes bem sucedidas irão se fixar como uma população distinta da parental, que é a “origem das espécies”. Para Levins e Lewontin (1985:32), as três proposições são os requisitos necessários e suficientes da evolução por seleção natural, e em nenhum dos três princípios há qualquer menção à adaptação. O conceito de adaptação diferencial surge em Darwin, de um lado por que a pergunta pelas "maravilhosas adaptações da natureza" era tradicional na história natural inglesa ${ }^{6}$, e também por que a "luta pela existência" (as ações do organismo "para" se manter vivo) seria um corolário de uma população crescendo exponencialmente em um mundo de recursos limitados, idéia que Darwin assumidamente retirou da teoria econômica de Malthus (Levins e Lewontin, 1985; Darwin, 2000; Vianna, 2006).

Apesar das advertências de Darwin sobre as metáforas utilizadas, e os contextos "sociológicos" da adaptação diferencial, termos como "seleção", "competição" e "valor adaptativo" assumiram, nos últimos 70 anos, significados bastante literais. É a emergência da Síntese Moderna, que na primeira metade do século XX estabeleceu-se como a versão canônica da biologia evolutiva, confluindo os desenvolvimentos da genética e das ciências naturais sob a lógica da seleção natural (Vianna, 2008). A resposta-padrão da Síntese para o fenômeno evolutivo é a de que "determinados genótipos são selecionados em um dado ambiente (a força diretiva da evolução), com a decorrente mudança na composição genética de uma população" (Vianna, 2008:135). Um elemento estrutural do organismo, os genes, contêm "informação" sobre o modo de construir corpos o mais habilidosos possível na competição pelo sucesso reprodutivo, disseminando os próprios genes em outros corpos. Diz Dawkins (1989:40) a respeito do que considera a essência do vivo, o "replicador":

As primeiras máquinas de sobrevivência provavelmente consistiram em nada mais do que um revestimento protetor [para os replicadores]. Mas viver tornou-se inexoravelmente mais difícil à medida que novos rivais surgiam com máquinas de sobrevivência melhores e mais eficientes. Estas se tornaram maiores e mais elaboradas, o processo sendo cumulativo e progressivo.

6. Exemplificando essa tradição, o reverendo William Paley, em 1809, considerou as adaptações como prova de um artífice inteligente: "se há um relógio, tem de haver um relojoeiro" (Vianna, 2006:124). 
E fecha, em um tom triunfal, sua obra O gene egoísta (Dawkins, 1989:222):

Somos construídos como máquinas gênicas e cultivados como máquinas mêmicas, mas temos o poder de nos revoltarmos contra nossos criadores. Somente nós, na Terra, podemos nos rebelar contra a tirania dos replicadores egoístas.

O que Dawkins explicitamente ignora em seu discurso é o próprio organismo, espremido entre os desafios do ambiente e as razões egoístas de proliferação dos genes. O organismo possui estatuto ontológico - é a "máquina de sobrevivência" dos genes - mas nenhuma agência: é uma bola de bilhar acionada pela interação entre duas instâncias causais: o taco da programação genética e a mesa das contingências ambientais. Ainda, a tal máquina de sobrevivência é uma entidade fixa (um eterno adulto?) desconsiderado todo o percurso ontogênico do organismo e as contínuas relações com o entorno desse organismo em desenvolvimento. O humano, por sua vez, apesar de naturalmente competitivo, como os demais, pode se libertar da natureza graças a uma adaptação singular: a cultura. Se os genes manipulam todos os corpos, entram em cena os "memes", programas que rodam apenas na mente humana, culturalmente herdados. Em linhas gerais, essa noção é bastante disseminada, inclusive nas ciências sociais, ao convergir as distinções humano-não-humano e natureza-cultura (ver discussão em Oyama, 2000b).

É notável a semelhança da evolução como representações diferenciais do ambiente no genoma, com a cognição como representações diferenciais da realidade na mente. Ao discurso cognitivista de menor ou maior aproximação do organismo a uma realidade objetiva, corresponde um discurso adaptacionista ${ }^{7}$, que fornece a chave histórica para a distribuição progressiva de organismos menos e mais “cognitivos” na evolução. É o que meu colega Rubén Gómez-Soriano e eu chamamos, parafraseando Lovejoy (1998), de "A Grande Cadeia da Cognição" (Gómez-Soriano e Vianna, 2008:179; Vianna e Gómez-Soriano, 2010) e o grande entrave epistemológico para uma compreensão adequada do viver do organismo.

Felizmente há alternativas, que vêm obtendo sucesso reprodutivo e disseminando seus memes pela literatura acadêmica. Ganha terreno a consideração do papel da ontogenia na evolução, e das ações do organismo durante a ontogenia, como proposto na Teoria dos Sistemas

7. Para uma excelente discussão e comparação das estratégias cognitivistas e adaptacionistas, ver Varela, Thompson e Rosch, 1997. 
em Desenvolvimento, ou DST (Oyama, 2000; Oyama, 2000b; Oyama, Griffiths e Gray, 2001). Nessa abordagem, inverte-se a relação tradicional em que a ontogenia é mera "expressão fenotípica” da herança genética. Na DST, cada organismo desenvolve-se em sua particularidade de modo contingente com suas próprias relações com o meio, e em sua regularidade na conservação e reprodução dos modos de relação de sua linhagem: a herança é sistêmica, não genética (Vianna, 2006:137-138). Nature (as características que definem um organismo em dado momento) não é genotípica, mas fenotípica, e nurture (as interações no desenvolvimento, em todos os níveis) é tão formativa de caracteres típicos e universais quanto atípicos e variáveis (Oyama, 2000b). A natureza é o produto dos processos de interação, não sua causa, ainda que essa natureza produzida permita a continuidade de apenas certos modos de interação: uma aplicação coerente da inescapável recursividade em uma visão sistêmica e responsável por conceitura a evolução, na DST, como evolução de sistemas em desenvolvimento.

Uma explicação sistêmica para a evolução orgânica é a Teoria da Deriva Natural, concebida, no contexto da Biologia do Conhecer, por Humberto Maturana e Jorge Mpodozis (1992). A teoria coloca como central, na história de diversificação dos seres vivos, o papel do comportamento, "a dinâmica de relações e interações que ocorrem no encontro do ser vivo com o meio em que realiza sua existência ao operar como tal" (Maturana e Mpodozis, 1992:9; tradução minha). Na deriva natural, a adaptação é uma invariante. Não há organismos mais ou menos adaptados, ou "estruturas adaptativas", pois toda dinâmica sistêmica do vivo, seja no curso do desenvolvimento ou na evolução, implica a conservação da adaptação como condição para a realização do viver. O organismo vive em contínuo acoplamento estrutural com o meio, ainda que seja determinado, a cada instante, por sua própria estrutura. Como o organismo muda sua estrutura em congruência com a história de interações, o fluir comportamental do ser vivo modula o curso de suas mudanças estruturais. Retire a adaptação, e o sistema vivo deixa de existir.

Como na DST, o organismo da deriva natural é um sistema ontogênico, ou seja, um sistema em desenvolvimento que muda sua estrutura a todo momento. Cada sistema ontogênico realiza esses processo em um modo de vida particular, que configura um sistema de determinada classe: uma linhagem. Na reprodução, é a conservação ou mudança do modo de vida que determina a manutenção dessa linhagem, ou, então, o estabelecimento de uma nova. Por exemplo, gorilas e humanos possuem modos de vida particulares, do ponto de vida das diferentes linhagens a 
que pertencem, fundadas nos respectivos percursos evolutivos. Mas, ao mesmo tempo, gorilas e humanos conservam um modo de vida de - digamos - "grandes símios africanos", que define, desse modo, uma organização comum. O modo de realizar essa organização deve ser igualmente conservado por gorilas e humanos, sem distinção, para que cada organismo pertencente à organização "grandes símios africanos" realize seu viver (por exemplo, o cuidado materno, a interação social e a utilização das mãos em uma série de circunstâncias).

Na reprodução, a estrutura fundadora de um novo ser vivo não ocorre de qualquer modo, mas "no âmbito particular determinado no viver do ser vivo progenitor" (Maturana e Mpodozis, 1992:17). Ao mudar sua relação específica com o meio - o domínio comportamental - um sistema ontogênico irá realizar sua organização de maneira diversa que os outros membros da linhagem, mas sempre no contexto inicial do modo de vida parental. Com a mudança comportamental, muda também o "genótipo total" (as possibilidades epigenéticas do organismo inicial, que inclui os genes e outros componentes constitutivos) da nova linhagem em relação à linhagem ancestral, configurando a mudança genética como secundária e dependente da relação organismo-meio.

Por isso o mecanismo gerativo da evolução é uma deriva natural: não houve uma força diretiva (uma "seleção") do fenótipo gorila na evolução, ainda que tenha havido, de fato, um curso filogenético observado, conservando aspectos do modo de vida dos grandes símios africanos e fundando duas novas linhagens: aquela que partilhamos com bonobos e chimpanzés, e a linhagem que N'kwango partilha com seus irmãos gorilas. O comportamento de N'kwango é sempre individual, mas ele partilha os modos de vida conservados na história das linhagens a que pertence.

\section{0 estabelecimento de um domínio lingüístico}

Recapitulando o que eu disse sobre a dinâmica do vivo na parte anterior, tanto o curso do desenvolvimento (a ontogenia) quanto da evolução, implicam a conservação da adaptação como condição para a realização do viver e, também, da continuidade de uma linhagem. O organismo e sua descendência vivem em contínuo acoplamento estrutural com o meio até, respectivamente, a morte individual ou a morte da linhagem. Como o fluir comportamental do ser vivo modula o curso de suas mudanças estruturais, o mesmo irá acontecer quando uma parte do meio com o qual o organismo interage é outro organismo. Suas respectivas ontogenias irão ocorrer num 
contexto coerente com a história de suas interações. Se as interações entre esses dois organismos são recorrentes e recursivas, ou seja, se observamos que existe uma história de interações entre esses organismos onde os respectivos comportamentos são incorporados à interações subsequentes, podemos dizer que esses organismos estão em um “domínio lingüístico" (Andrade, Reis e Vianna, 2010:40): um domínio comportamental de ações coordenadas, consensuais, entre dois ou mais organismos. E sempre que houver um domínio lingüístico, uma rede social pode ser formada como uma rede de interações consensuais e recursivas entre os membros de uma mesma comunidade de organismos: uma cultura.

Quanto à ausência ou presença, na observação de interações nãohumanas, daqueles elementos comportamentais tradicionalmente descritos como pertencentes à linguagem humana - fala, sinais gestuais, escrita - é preciso entender que, se aceitamos o caminho explicativo que estou utilizando aqui, nenhum som, gesto ou desenho particular faz parte, de antemão, da linguagem, pois essa é definida historicamente. Se há recursão, se no curso da interação aquele som, gesto ou desenho é distinguido como um elemento na coordenação de ações consensuais, ele fará parte da linguagem na descrição do observador. O mesmo se dá com outras regularidades percebidas na língua, como a sintaxe. É preciso fazer referência à história, ao curso de interações, para se dizer que uma palavra ou frase pertence à linguagem. A dificuldade de atribuirmos linguagem a organismos não-humanos é que, na maioria das vezes (por razões históricas: evolutivas e ontogênicas), não participamos com eles de interações recorrentes e recursivas, e, portanto, não somos capazes de descrever suas interações como consensuais.

Essa relação estabelecida entre dois ou mais organismos, a co-ontogenia (Vianna, 2006:308-313), é, portanto um tipo particular do modo de vida de qualquer ser vivo, a relação organismo-meio. Tal como acontece na dinâmica das relações com o meio, os dois (ou mais) organismos em acoplamento estrutural irão mudar suas estruturas de modo correspondente, na interação. Se essa história de relações durar o suficiente, se for recorrente e recursiva, temos o estabelecimento de um domínio lingüístico, base da formação de um sistema social e de uma cultura (uma rede de sistemas vivos em coordenação consensual de ações). Assim, se atentarmos, não para o "conteúdo" ou a "forma” dessas relações - para os elementos que são utilizados no processo de interação ou a maneira como são utilizados -, mas prestarmos atenção na recursividade do processo interacional co-ontogênico, estaremos decrevendo os fundamentos biológicos do fenômeno da linguagem. 


\section{Conclusão: nós e o espaço relacional da linguagem}

Costumamos considerar o comportamento como algo facilmente mutável, ou, pelo menos, mais maleável do que a constituição biológica. Se levarmos a sério o caminho explicativo que expus acima, no entanto, a situação é bem outra. Modos de vida, ou seja, as relações estabelecidas com o meio, são modos específicos de realizar a organização - seja humana, símia ou mamífera, no nosso caso - e necessariamente conservadores, pois implicam a própria manutenção de nossa condição de ser-e-estarvivos - durante a ontogenia - e a continuidade da linhagem, no fenômeno da reprodução. Mesmo no estabelecimento de uma nova linhagem, parte do modo de vida é conservado, pois todo organismo realiza sua ontogenia inicial no contexto do modo de vida parental. Nossa constituição orgânica, por outro lado, pode variar imensamente: pode variar tanto quanto permita a realização do nosso viver. Mesmo enquanto indivíduos, estamos em permanente mudança estrutural por toda a ontogenia.

Se prestarmos atenção a um grupo qualquer de seres humanos, nos impressionamos com o modo como uma gama enorme de estruturas anatômicas e fisiológicas são todas adequadas a um modo de vida comum, a uma mesma rede de relações sociais e conversações que configura a cultura. E mesmo entre as mais variadas culturas humanas é conservado um modo de vida que tem a ver com a história única de nossa linhagem, e que nos diferencia fundamentalmente de outros organismos, assim como outras linhagens de organismos se diferenciam entre si. É isso o que distingüimos quando dizemos que só o humano "tem linguagem”, ou só o humano "tem cultura": o curso da evolução se encarrega, inexoravelmente, de produzir um hiato comportamental que só podemos apreciar se notarmos, ao mesmo tempo, que esse hiato permeia o restante da diversidade viva.

Ao contemplar outra organização que também faz parte de nós, humanos - a de grandes símios - identificamos rapidamente as enormes diferenças nos atributos físicos, ou, pelo menos entre “nós” e “eles" (nem todos sabemos distingüir um orangotango de um gorila, apesar de sermos mais aparentados ao gorila que o organgotango). Mas se atentarmos para os modos de vida que foram conservados em nossa antiga linhagem de grandes símios (que remonta a mais de 10 milhões de anos) nos impressionamos com o fato de seres tão diferentes realizarem coisas tão parecidas: a criação amorosa dos filhotes, a intricada rede social, o manuseio de alimentos e de outros objetos, a confecção (manual) de instrumentos e muitos outros modos de conhecer, ou seja, de operar em 
interação com os elementos do entorno que nos permitem realizar nossa organização de grandes símios.

A principal divergência entre as descrições que fiz aqui e o quadro conceitual da Biologia do Conhecer, é que, nesse sistema explicativo, é preciso não apenas que haja coordenações de ações (o domínio lingüístico que descrevi acima), mas coordenações de coordenações de ações, ou seja, que os próprios elementos do encontro recorrente (sons, gestos ou grafismos, entre outras formas de expressão) sejam utilizado, recursivamente, no processo de coordenar ações dos organismos. Para Maturana, é na linguagem (ou "linguajar"; ver Maturana, 1997b:175) que surge o humano, e, como modo de conservar sua organização, o humano vive nesse "fluir de interações recorrentes" (Maturana, 1997b:168). Concordo com Maturana até certo ponto, especificamente sobre o que ele diz sobre “denotação” (Maturana, 1997:150):

[Denotação] não é uma operação primitiva. Ela requer concordância - consenso - para a especificação tanto do denotante quanto do denotado. Se a denotação, portanto, não é primitiva, não pode ser tampouco uma operação lingüística primitiva.

É por concordar com a Biologia do Conhecer sobre o que é uma operação primitiva - o domínio consensual - que considero a realização do domínio consensual humano na linguagem um caso particular do espaço relacional co-ontogênico em que vive todo e qualquer organismo. Tudo aquilo que argumentei sobre a cognição e a evolução - ou seja, que apontar para informações prévias no mundo ou na mente não explica o fenômeno do conhecer, e apontar para informações prévias no ambiente ou no genoma não explica o fenômeno da evolução -, serve, igualmente, para a linguagem. Considero relevante o estudo do código lingüístico, como fazem as ciências lingüísticas das maneiras mais variadas e produtivas. Minha objeção é a afirmação de que esse código é o produto de uma cognição privilegiada, ou o produto de uma evolução cognitiva diferenciada no surgimento da linhagem humana. Sendo seres humanos, não podemos abdicar da linguagem humana para fazer o que quer que seja, e isso, na tradição do pensamento ocidental, tem sido confundido com uma capacidade superior de representar a realidade por meio do atributo lingüístico. Penso, ainda, que embora o fenômeno particular da linguagem humana mereça um explicação biológica particular, o fenômeno da interação co-ontogênica recursiva é tão gerativo da linguagem humana quanto de outros domínios lingüísticos não-humanos. 
Quando a linhagem humana divergiu da linhagem que deu origem aos atuais bonobos e chimpanzés, os organismos humanos passaram a conversar entre si de modo distinto da realização co-ontogênica da linhagem ancestral. Do mesmo modo, nós, o grupo humano-bonobo-chimpanzé, divergimos da linhagem de N'kwango - os gorilas - em um passado mais distante, e este outro "nós" divergiu da linhagem de Padana - os orangotangos - há mais tempo ainda. Esses grupos foram, à medida em que surgiam como populações distintas, deixando de "conversar" (realizar suas co-ontogenias) entre si. A linguagem vista como espaço relacional, e, não, como um atributo possuído ou não pelos organismos, está de fato implicada na evolução, mas de modo inverso do que costumamos encontrar nos estudos sobre “evolução da linguagem”. É a conservação - ou ruptura -, dos domínios lingüísticos consensuais que permite a conservação - ou a ruptura -, das populações de organismos. Se você já ouviu várias definições de evolução, apresento mais essa: evolução é a evolução de domínios lingüísticos distintos.

Os macacos africanos vervet (Chlorocebus aetiops) tornaram-se personagens famosos das ciências cognitivas, tão logo descobrimos que esses animais emitem diferentes chamados de alarme para diferentes tipos de predadores (Seyfarth, Cheney e Marler, 1980). Ao ouvir um chamado, um vervet, alternativamente: corre para a segurança das árvores, ou então fica ereto na grama, atento ao chão, ou, ainda, procura abrigo nas moitas, olhando para o céu. O vervet ouviu seus co-específicos dizerem, respectivamente, "leopardo", "cobra" e "águia". Os cientistas foram bastante engenhosos em descobrir uma "semântica vervet". Parece, afinal, que outros organismos, além do humano, denotam coisas no mundo. Mas os cientistas de fato sabem o que dizem os vervet? O significado é mesmo "leopardo", "cobra" e "águia"? Eu me arrisco a dizer que, se um cientista conhecesse a linguagem vervet, ele não daria descrições semânticas desse comportamento, nem comunicaria o fato a seus pares, mas, antes, trataria de correr para a segurança das árvores, ou então ficaria ereto na grama, atento ao chão, ou, ainda, procuraria abrigo nas moitas, olhando para o céu, em um significativo medo ancestral. 


\section{Referências bibliográficas}

Andrade, L. A., Reis, L. B. e Vianna, B. (2010). Corporeidade, cognição e linguagem. Ciências e Cognição, 15(3):033-046.

Bradley, B.; Doran-Sheehy, D.; Lukas D. e Boesch, C. (2004). Dispersed Male Networks in Western Gorillas. Current Biology, 14:510-513.

Darwin, C. (1974) [1871]. A origem do homem e a seleção sexual. (A. Cancian e E. N. Fonseca, Trad.). São Paulo: Hemus.

Darwin, C. (2000) [1887]. Autobiografia: 1809-1882. (V. Ribeiro, Trad.). Rio de Janeiro: Contraponto.

Darwin, C. (2002) [1859]. A origem das espécies. (E. Amado, Trad.). Belo Horizonte: Itatiaia.

Dawkins, R. (1989) [1976]. O gene egoísta. (G. Florsheim, Trad.). Belo Horizonte: Itatiaia. Geertz, C. (2001) [2000]. Anti anti-relativismo. Em: Nova luz sobre a antropologia. C. Geertz, Ed. (V. Ribeiro, Trad.). Rio de Janeiro: Zahar.

Gómez-Soriano, R. e Vianna, B. (2008). Demasiado mono: versiones occidentales de los grandes simios. Em: Tecnogénesis: la construcción técnica de las ecologías humanas T. Sánchez-Criado, Ed. Madrid: Antropólogos Iberoamericanos en Red.

Gould, S. J. (2003) [1998]. Um cavalo-marinho para todos os corredores. Em: A montanha de moluscos de Leonardo da Vinci. S. J. Gould. (R. Rubino, Trad.). São Paulo: Cia. das Letras.

Groves, C. (2001). A history of gorilla taxonomy. Em: Gorilla biology: a multidisciplinary perspective. A. Taylor e M. Goldsmith, Eds. Cambridge: Cambridge University Press.

Hanus, D. e Call, J. (2007). Discrete Quantity Judgments in the Great Apes (Pan paniscus, Pan troglodytes, Gorilla gorilla, Pongo pygmaeus): The Effect of Presenting Whole Sets Versus Item-by-Item. Journal of Comparative Psychology, 121(3):241-249.

Huxley, T. H. (2001) [1863]. Man's place in nature. New York: Modern Library, 2001.

Kant, I. (1980) [1781]. Crítica da razão pura. (V. Rohden e U. Moosburger, Trad.) São Paulo: Abril Cultural.

Latour, B. (1993). We have never been modern. Cambridge: Harvard Universtity Press. Lovejoy, A. (1998) [1936]. The great chain of being. Cambridge: Harvard University Press. Kuhn, T. (2001) [1962]. A estrutura das revoluções científicas. (B. V. Boeira e N. Boeira, Trad). São Paulo: Perspectiva.

Maturana, H. (1997). Biologia da linguagem: a epistemologia da realidade. (C. Magro, Trad.). Em: A ontologia da realidade. C. Magro, M. Graciano e N. Vaz, Orgs. Belo Horizonte: Editora UFMG.

Maturana, Humberto (1997b). Ontologia do conversar. (C. Magro e N. Vaz, Trad.). Em: A ontologia da realidade. C. Magro, M. Graciano e N. Vaz, Orgs. Belo Horizonte: Editora UFMG.

Maturana, H. e Mpodozis, J. (1992). Origen de las especies por medio de la deriva natural. 
Santiago de Chile: Dirección de Bibliotecas, Archivos y Museos.

Maturana, H. e Varela, F. (1973). De máquinas y seres vivos: una teoría de la organización biológica. Santiago de Chile: Editorial Universitaria.

Maturana, H. e Varela, F. (1998). The tree of knowledge: biological roots of human understanding. Boston: Shambala.

Oyama, S. (2000). The ontogeny of information: Developmental systems and evolution. $2 \mathrm{a}$. edição revisada e expandida. Durham: Duke University Press.

Oyama, S. (2000b). Evolution's eye: A systems view of the biology-culture divide. Durham: Duke University Press.

Oyama, S.; Griffiths, P. e Gray, R. (Eds.) (2001). Cycles of contingency: Developmental systems and evolution. Cambridge: MIT Press/Bradford Books.

Platão. (1994). Crátilo: diálogo sobre a justeza dos nomes. (D. Palmeira, Trad.). Lisboa: Livraria Sá da Costa Editora.

Rorty, R. (1994) [1979]. A filosofia e o espelho da natureza. (A. Trânsito, Trad.). Rio de Janeiro: Relume-Dumará.

Saussure, F. (1992) [1916]. Curso de linguística geral. (A. Chelini. J. P. Paes e I. Blikstein, Trad.). São Paulo: Cultrix.

Seyfarth, R., Cheney, D. e Marler, P. (1980). Monkey responses to three different alarm calls: Evidence for predator classification and semantic communication. Science, 210 :801-803.

Teixeira Coelho Netto, J. (1999). Semiótica, informação e comunicação. São Paulo: Perspectiva.

Trask, Robert Lawrence. (2006) [2004]. Dicionário de linguagem e lingüística. (R. Ilari, Trad.). São Paulo: Contexto.

Varela, Francisco; Thompson, Evan e Rosch, E. (1997). The embodied mind. Cambridge: MIT Press.

Vianna, B. (2004). Sombras na batcaverna: a charada cartesiana, o coringa kantiano, e os pingüins de Darwin. Revista USP, 63:169-174.

Vianna, B. (2008). Desde Darwin: Spock e a deriva natural. Em: Biologia da libertação: ciência, diversidade e responsabilidade. B. Vianna, Ed. Belo Horizonte: Mazza edições.

Vianna, B. e Gómez-Soriano, R. (2007). Grandes símios em linguagem: um crítica do conceito de evolução à luz das abordagens sistêmicas. Anales del I Congreso Iberoamericano de Antropología. Edição eletrônica. Havana.

Vianna, B. e Gómez-Soriano, R. (2010). “Inglourious primates”: grandes símios entre o objeto, o modelo e o outro do humano. Comunicação apresentada na $27^{\mathrm{a}}$ Reunião Brasileira de Antropologia. Belém, 4 de agosto.

Vianna, H. (2006). Nós primatas em linguagem: relações lingüísticas como um processo biológico. Tese de doutorado não-publicada, Programa de Pós-graduação em Estudos Lingüísticos, Universidade Federal de Minas Gerais. 